\title{
Correction to: Morphometric and molecular analyses of Carassotrema koreanum park 1938 and Elonginurus mugilus Lu 1995 (Digenea: Haploporidae) Srivastava, 1937 from the Russian Far East and Vietnam
}

\author{
Dmitry M. Atopkin ${ }^{1,2}$. Vladimir V. Besprozvannykh ${ }^{1}$ - N. D. Ha ${ }^{3}$ - H. V. Nguyen ${ }^{3}$ - Alexandra Yu Khamatova ${ }^{1}$. \\ Konstantin S. Vainutis ${ }^{1}$
}

Published online: 18 June 2019

(C) Springer-Verlag GmbH Germany, part of Springer Nature 2019

Correction to: Parasitology Research

https://doi.org/10.1007/s00436-019-06328-4

The original version of this article contained mistake in the accession number found in Table 1. Correct accession numbers are presented here.

Table 1 List of taxa used for molecular analysis

\begin{tabular}{|c|c|c|c|c|c|}
\hline \multirow[t]{2}{*}{ Species } & \multirow{2}{*}{$\begin{array}{l}\text { N (28S/ } \\
\text { ITS) }\end{array}$} & \multirow{2}{*}{$\begin{array}{l}\text { Definitive } \\
\text { host }\end{array}$} & \multirow[t]{2}{*}{ Authors } & \multicolumn{2}{|c|}{ Accession number in the NCBI } \\
\hline & & & & $28 \mathrm{~S}$ & ITS1-5.8S-ITS2 \\
\hline $\begin{array}{c}\text { Carassotrema } \\
\text { koreanum }\end{array}$ & $3 / 3$ & $\begin{array}{c}\text { Carassius } \\
\text { gibelio }\end{array}$ & $\begin{array}{l}\text { Present } \\
\text { study }\end{array}$ & MK387334-MK387336 & MK387334-MK3873 \\
\hline
\end{tabular}

Publisher's note Springer Nature remains neutral with regard to jurisdictional claims in published maps and institutional affiliations.

The online version of the original article can be found at https://doi.org/ $10.1007 / \mathrm{s} 00436-019-06328-4$

Dmitry M. Atopkin

atop82@gmail.com

1 Federal Scientific Center of the East Asia Terrestrial Biodiversity, Far Eastern Branch of the Russian Academy of Sciences,

Vladivostok, Russia

2 Department of Cell Biology and Genetics, Far Eastern Federal University, Vladivostok, Russia

3 Institute of Ecology and Biological Resources, Vietnamese Academy of Sciences and Technology, Hanoi, Vietnam 